\title{
HUBUNGAN SHIFT KERJA DENGAN STRES KERJA PADA KARYAWAN BAGIAN OPERATION PT. NEWMONT NUSA TENGGARA DI KABUPATEN SUMBAWA BARAT
}

\author{
Andri Satriadi Firmana, Widodo Hariyono \\ Fakultas Kesehatan Masyarakat, Universitas Ahmad Dahlan, Yogyakarta
}

\begin{abstract}
Background: Work shift is one of major source of job stress for workers that affect the biological, psychological and social life. Stress can happen in a short notice, but also can happen in a long moment. The excessive stress to threaten a person's ability to cope with the environment. The objective of this study is to determine the relationship shifts with work stress on the operation of PT. Newmont Nusa Tenggara in West Sumbawa regency.

Method: This was an observational research with cross sectional design. The population of this study consists of 250 employees of the operation crew A of PT. Newmont Nusa Tenggara. The research sample is some staff the operation crew of A PT. Newmont Nusa Tenggara. The sampling used is proportionate with stratified random sampling technique. The sample takes 71 people. Analysis of descriptive data using frequency distribution tables and analytically to determine the relationship between two variables with bivariate data analysis, chi-square test.

Result: The results showed a significant relationship between work shift and work stress with chi square value of 5.329 compared with T-score tables 3,841 on $\mathrm{df}=1$ at $\alpha=5$ percent $(0.05)$ and prevalence ratio $(\mathrm{RP})=2065(95 \% \mathrm{Cl}=1.093-3.89)$, so that $\mathrm{Ho}$ refused and $\mathrm{Ha}$ accepted.

Conclusion: : Independent variables studied (work shift) has a significant relationship to job stress.
\end{abstract}

Keywords: Work shift, Work stress

\section{PENDAHULUAN}

Produktivitas perusahaan sangat dipengaruhi oleh kualitas sumber daya manusia yang ada dalam perusahaan. Sumber daya tersebut adalah karyawan yang memiliki profesionalisme dan integritas. Profesionalisme tersebut salah satunya dapat dikembangkan melalui intensitas shift kerja yang baik sehingga ke depannya dapat meningkatkan produktifitas. Shift kerja yang ada tidak dapat diatur dengan baik akan mempengaruhi kinerja karyawan dan salah satunya adalah berupa stres kerja. ${ }^{1}$

Berdasarkan hasil wawancara pada tanggal 13 April 2010 yang dilakukan oleh peneliti kepada salah satu karyawan bagian personalia PT. Newmont Nusa Tenggara (PT. NNT) yang berlokasi di Kabupaten Sumbawa Barat, Perusahaan Pertambangan Emas ini menerapkan sistem kerja bergilir atau sistem kerja shift, yang dibagi dalam dua shift yaitu: shift I (pagi) mulai jam 06.00-18.00, shift II (malam) mulai jam 18.0006.00, dengan diselingi rehat waktu sholat, makan, atau keperluan emergency lainnya. Hasil wawancara pada tanggal 25 Maret 2010 dengan beberapa orang karyawan, yang bekerja pada perusahaan tersebut didapatkan banyak keluhan mengenai shift kerja malam, seperti; 1) gangguan tidur; 2) gangguan pencernaan; 3) kelelahan; 4) kecelakaan kerja; 5) gangguan kehidupan sosial seperti sulit untuk menyesuaikan waktu dengan keluarga dan mengikuti kegiatan sosial kemasyarakatan di lingkungan tempat tinggal mereka yang biasa dilakukan pada sore atau malam hari.

Berdasarkan studi pendahuluan peneliti tertarik ingin meneliti masalah ini dengan judul "Hubungan antara Shift Kerja dengan Stres Kerja pada Karyawan Bagian Operasi PT. Newmont Nusa Tenggara di Kabupaten Sumbawa Barat". 


\section{METODE PENELITIAN}

Penelitian ini merupakan penelitian analitik observasional dengan menggunakan rancangan studi potong lintang (cross sectional). Populasi adalah ini adalah semua karyawan bagian operation crew A yang bekerja pada PT. NNT berjumlah 250 orang, sedangkan sampel adalah sebagian yang diambil dari keseluruhan objek peneltian dan diannggap mewakili seluruh populasi. Jumlah sampel sebanyak 71 orang karyawan. Teknik pengambilan sampel yang digunakan adalah dengan teknik proportionate stratified random sampling.

Alat dalam penelitian ini adalah menggunakan kuesioner. Kuesioner digunakan untuk mengukur tingkat stres kerja pada responden. Pengolahan data dilakukan dengan bantuan komputer dengan program statistik dengan uji chi-square untuk mengetahui hubungan antara variabel bebas dengan variabel terikat. Analisis data meliputi analisis univariat, dan bivariat. Adapun langkah-langkah dalam analisis untuk menguji hubungan antara variabel meliputi:

1. Secara deskriptif dengan menggunakan tabel distribusi frekuensi.

2. Secara analitik untuk mengetahui hubungan antara dua variabel menggunakan uji chi -square.

\section{HASIL PENELITIAN DAN PEMBAHASAN}

\section{a. Hasil Penelitian}

Hasil analisis bivariat variabel bebas dengan kejadian stres pada pada karyawan bagian operation PT. Newmont Nusa Tenggara di Kabupaten Sumbawa Barat adalah sebagai berikut :

Tabel 1. Hubungan antara Shift Kerja dengan Stres Kerja pada Karyawan Bagian Operation PT. Newmont Nusa Tenggara di Kabupaten Sumbawa Barat tahun 2010.

\begin{tabular}{|c|c|c|c|c|c|c|c|c|}
\hline \multirow{3}{*}{$\begin{array}{l}\text { Shift } \\
\text { Kerja }\end{array}$} & \multicolumn{4}{|c|}{ Stres Kerja } & \multirow{2}{*}{\multicolumn{2}{|c|}{ Total }} & \multirow[t]{2}{*}{ Value } & \multirow{3}{*}{$\begin{array}{c}R P \\
(95 \% \mathrm{Cl})\end{array}$} \\
\hline & \multicolumn{2}{|c|}{$\begin{array}{l}\text { Stres } \\
\text { Ringan }\end{array}$} & \multicolumn{2}{|c|}{$\begin{array}{l}\text { Stres } \\
\text { Sedang }\end{array}$} & & & & \\
\hline & $n$ & $(\%)$ & $\mathrm{N}$ & $(\%)$ & $n$ & $(\%)$ & & \\
\hline Malam & 15 & 21,1 & 16 & 22,5 & 31 & 43,7 & & 2,065 \\
\hline Pagi & 30 & 42,3 & 10 & 14,1 & 40 & 56,3 & & $3,899)$ \\
\hline Total & 45 & 63,4 & 26 & 36,6 & 71 & 100 & & \\
\hline
\end{tabular}

Hasil uji analisis data menunjukkan bahwa, dapat disimpulkan ada hubungan yang bermakna antara shift kerja dengan stres kerja pada karyawan bagian operation PT. Newmont Nusa tenggara di kabupaten Sumbawa Barat dengan nilai value atau chi-square 5,329 dibandingkan dengan nilai $\mathrm{T}$ tabel 3,841 pada $\mathrm{df}=1$ dan rasio prevalensi $(\mathrm{RP})=2,065(\mathrm{Cl} 95 \%=1,093-3,89)$

\section{b. Pembahasan}

1) Shift Kerja

Berdasarkan hasil penelitian yang dilakukan terhadap 71 karyawan karyawan bagian operation PT. Newmont Nusa Tenggara, sebagian besar 
bekerja pada shift pagi berjumlah 40 karyawan $(56,3 \%)$ dan yang bekerja pada shift malam berjumlah 31 karyawan $(43,7 \%)$. Pada shift pagi yang mengalami stres ringan sebesar 30 karyawan $(42,3 \%)$ dan stres sedang sebesar 10 karyawan $(14,1 \%)$ sedangkan pada shift malam yang mengalami stres ringan sebesar 15 orang $(21,1 \%)$ dan stres sedang sebesar 16 orang $(22,5 \%)$. Hasil ini menunjukkan bahwa shift kerja malam lebih berisiko untuk terjadinya stres sedang dibandingkan shift kerja pagi.

Nogawa dkk, (2005) $)^{2}$ dalam penelitian mereka terhadap 4.962 pekerja pabrik baja menemukan adanya peningkatan stres kerja pada pekerja dengan shift dibandingkan dengan pekerja tanpa shift. Wahyu $(2000)^{3}$ menyimpulkan bahwa shift kerja berpengaruh terhadap tingkat stres tenaga kerja dan paling tinggi berada pada shift malam.

2) Stres Kerja

Pada hasil analisis univariat yang dilakukan pada 71 karyawan bagian operation PT. Newmont Nusa Tenggara, sebagian besar mengalami stres ringan sebesar 45 orang $(63,4 \%)$ dan yang mengalami stres sedang sebesar 26 orang $(36,6 \%)$. Karyawan yang bekerja pada shift pagi yang mengalami stres ringan sebesar 30 orang $(42,3 \%)$ dan stres sedang sebesar 10 orang $(14,1 \%)$ hal ini bisa diakibatkan karyawan yang bekerja pada shift pagi mempunyai waktu istirahat yang lebih banyak dan penerangan saat bekerja yang cukup sehingga beban kerja tidak terlalu berat.

Sebaliknya karyawan yang bekerja pada shift malam yang mengalami stres ringan sebesar 15 orang $(21,1 \%)$ dan stres sedang sebesar 16 orang $(22,5 \%)$ dari hasil data ternyata karyawan yang mengalami stres sedang dan stres ringan berjumlah hampir sama, salah satunya bisa saja dialami karyawan karena pekerjaan pada shift malam banyak terdapat kegiatan kerja lembur sehingga waktu istirahat sedikit.

Hal ini disebabkan motivasi kerja pada karyawan bagian operation PT. Newmont Nusa Tenggara di Kabupaten Sumbawa Barat cukup tinggi didukung juga upah kerja yang diberikan oleh PT. NNT kepada karyawan sangat sesuai dengan pekerjaan yang mereka lakukan, ditambah pada tiap lima tahun lama kerja mereka diberikan sebuah penghargaan berupa medali emas seberat $5 \mathrm{gr}$. Lawler menyatakan bahwa upah/gaji dapat digunakan sebagai sumber suatu motivasi, maka tingkat-tingkat tinggi kinerja kerja, harus dipandang sebagai alur melalui apa orang dapat mencapai upah/gaji tinggi. ${ }^{4}$

3) Hubungan Shift Kerja dan Stres Kerja

Hasil analisis uji bivariat menunjukkan ada hubungan yang bermaka antara shift kerja dan stres kerja dengan nilai value atau chi square 5,329 dibandingkan dengan nilai $\mathrm{T}$ tabel 3,841 pada $\mathrm{df}=1$ berarti Ho ditolak, adapun nilai rasio prevalensi $(\mathrm{RP})=2,065(\mathrm{Cl} 95 \%=1,093-3,89)$. Dengan ini, variabel tersebut memiliki keterkaitan untuk meningkatkan reduksi stres tenaga kerja pada karyawan bagian operation PT. Newmont Nusa Tenggara di Kabupaten Sumbawa Barat.

Faktor yang mendorong untuk terjadinya stres kerja pada karyawan bagian operation PT. Newmont Nusa Tenggara di Kabupaten Sumbawa Barat diakibatkan karena adanya intensitas lamanya kerja fisik dan mental, akibat jenis pekerjaan yang monoton, beban tanggung jawab pekerjaan, dan adanya lingkungan fisik yang kurang baik seperti kebisingan dan suhu ruangan yang panas secara subyektif. Didukung juga dengan hasil penelitian yang dilakukan oleh peneliti dari uji chi-square menunjukkan bahwa ada hubungan antara shift kerja dan stres kerja. 
Hasil penelitian ini sejalan dengan penelitian yang dilakukan oleh Solipah $(2007)^{5}$, diperoleh hasil bahwa adanya hubungan yang bermakna antara shift kerja dengan stres kerja pada tenaga kerja bagian produksi PT. CJFI Group di Indramayu. Monk \& Tepas menyatakan shift kerja malam merupakan sumber utama dari stres bagi para pekerja pabrik. ${ }^{6}$ Para pekerja shift lebih sering mengeluh tentang kelelahan dan gangguan perut daripada pekerja pagi/siang dan dampak dari kerja shift terhadap kebiasaan makan yang mungkin menyebabkan gangguan perut. Pengaruhnya adalah emosional dan biologikal, karena gangguan ritme circadian dari tidur/daur keadaan bangun (wake cycle), pola suhu, dan ritme pengeluaran adrenalin.

\section{SIMPULAN DAN SARAN}

\section{a. Simpulan}

Ada hubungan antara shift kerja dan stres kerja pada karyawan bagian operation PT. Newmont Nusa tenggara di Kabupaten Sumbawa Barat dengan nilai value atau chi-square 5,329 dibandingkan dengan nilai $\mathrm{T}$ tabel 3,841 pada $\mathrm{df}=1$ dan rasio prevalensi $(\mathrm{RP})=2,065(\mathrm{Cl} 95 \%=1,093-3,89)$

\section{b. Saran}

1) Bagi Pimpinan Pabrik Tenun "Agung Saputra Tex" Kabupaten Bantul.

Apabila selama ini belum/sudah pernah menyelenggarakan kegiatan rekreasi bagi tenaga kerja, disarankan untuk mengagendakan kegiatan rekreasi tersebut secara teratur dan terencana sebagai bagian dari manajemen kesehatan tenaga kerja

2) Bagi Dinas Kesehatan Kabupaten Bantul.

Perlu adanya upaya penyuluhan yang berkesinambungan kepada karyawan bagian operation mengenai faktor risiko yang dapat menyebabkan terjadinya stres kerja. Agar karyawan dapat menghindari faktor risiko dan mencegah secara dini penyebab terjadinya stres kerja.

\section{DAFTAR PUSTAKA}

1. Agus, Stres Kerja, Patogenesa dan Penanganannya, Majalah Kedokteran Daminatus, 5 (1): 41- 50, 2006

2. Nogawa, dkk, Three-Shift System Increases Job-Related Strees in Japanese Workers, Journal, 47: 397-404, 2005

3. Wahyu, A., Pengaruh Shift Kerja dan Lama Kerja Terhadap Stres dan Kepuasan Kerja Pada Tenaga Kerja Wanita, Tesis, Program Studi Ilmu Kesehatan Kerja, Program Pascasarjana Fakultas Kedokteran, Universitas Gadjah Mada, Yogyakarta, 2000

4. Winardi, Motivasi dan Pemotivasian dalam Manajemen, PT. Raja Grafindo, Jakarta, 2004

5. Solipah, Hubungan Shift Kerja dengan Stres Kerja Pada Tenaga Kerja Bagian Produksi PT. CJFI Group di Indramayu, Skripsi, Fakultas Kesehatan Masyrakat, Universitas Ahmad Dahlan, Yogyakarta, 2007

6. Munandar, A.S., Psikologi Organisasi dan Industri, Universitas Indonesia Press, Jakarta, 2006 